\title{
ДЛИТЕЛЬНАЯ РЕМИССИЯ ИДИОПАТИЧЕСКОГО САХАРНОГО ДИАБЕТА 1 ТИПА НА ФОНЕ НИЗКОУГЛЕВОДНОЙ БЕЗГЛЮТЕНОВОЙ ДИЕТЫ
}

\section{Зильберман Л.И., Бричева Э.Б., Еремина И.А., Лаптев Д.Н.}

ФГБУ «Национальный медицинский исследовательский центр эндокринологии» Минздрава России

Распространенность Идиопатического Сахарного диабета 1 типа (с отсутствием специфических панкреатических аутоантител) составляет около 15\%. Клиническая картина и течение заболевания не имеет существенных отличий от аутоиммунного СД 1 типа. В случае ранней диагностики заболевания отмечается прогрессивное снижение секреции инсулина и С-пептида со скоростью около $10 \%$ в месяц, и через 6-12 месяцев развивается инсулинопотребность (Andersen MLM, 2012). Приводим наше наблюдение.

Клинический случай: Мальчик Ф., 2006 г.р., в мае 2019 года, в возрасте 13 лет обратился к врачу с жалобами на пиодермию на лице. При обследовании гликемия натощак - 6,0 ммоль/л, НbА1c $-6,4 \%$. Наследственность по СД не отягощена. Рекомендована низкоуглеводная диета. Через 3 месяца: НbA1c - 5,7\%. В октябре 2020 года начали отмечать повышение гликемии натощак до 8,0 ммодь/л, НbA1C5,6\%. Проведен пероральный глюкозотолерантный тест (ПГТТ): гликемия натощак - 5,5 ммоль/л, на 60 мин - 17,4 ммоль/л, на 120 мин - 20,8 ммоль/л. Родители в рационе исключили быстроусвояемые углеводы и глютен, сократили медленноусвояемые углеводы до 2ХЕ в сутки, увеличили содержание белка. В июле 2021 после перенесенной новой коронавирусной инфекции отметили повышение гликемии натощак до 7,0 ммоль/л и 11,6 в течение дня, присоединилось чувство жара и гиперемия лица, гипергидроз при физической и психоэмоциональной нагрузке. Инициирована интенсифицированная схема инсулинотерапии детемир и аспарт 0,1 ЕД/кг/сут, расширен рацион питания.

Госпитализирован в ФГБУ "НМИЦ эндокринологии" Минздрава России в октябре 2021 года (нарушение углеводного обмена в течение 2,5 лет). Инсулинотерапия при поступлении: детемир (5 ЕД) и аспарт (1 ЕД на $1 \mathrm{XE}$, всего $4 \mathrm{XE}), 0,16$ ед/кг в сутки.

При обследовании рост 171,5 cм, (SDS -0,086), масса тела 59 кг, ИМТ 20,2 кг/м2 (SDS -0,003). В биохимическом анализе крови диагностирована дислипидемия (холестерин общий - 5,26 ммоль/л (3,3$5,2)$, ЛПНП - 3,39 ммоль/л (1,1-3)). Кетоны в ОАМ отсутствуют. НbА1c - 7,4\%. Базальный уровень инсулина - 2,22 мкЕ/мл $(2,6-24,9)$, через 90 мин после завтрака - 6,01 мкЕ/мл. С-пептид - 0,6 нг/мл $(1,1-4,4)$.

Рисунок 1. Динамика показателей углеводного обмена

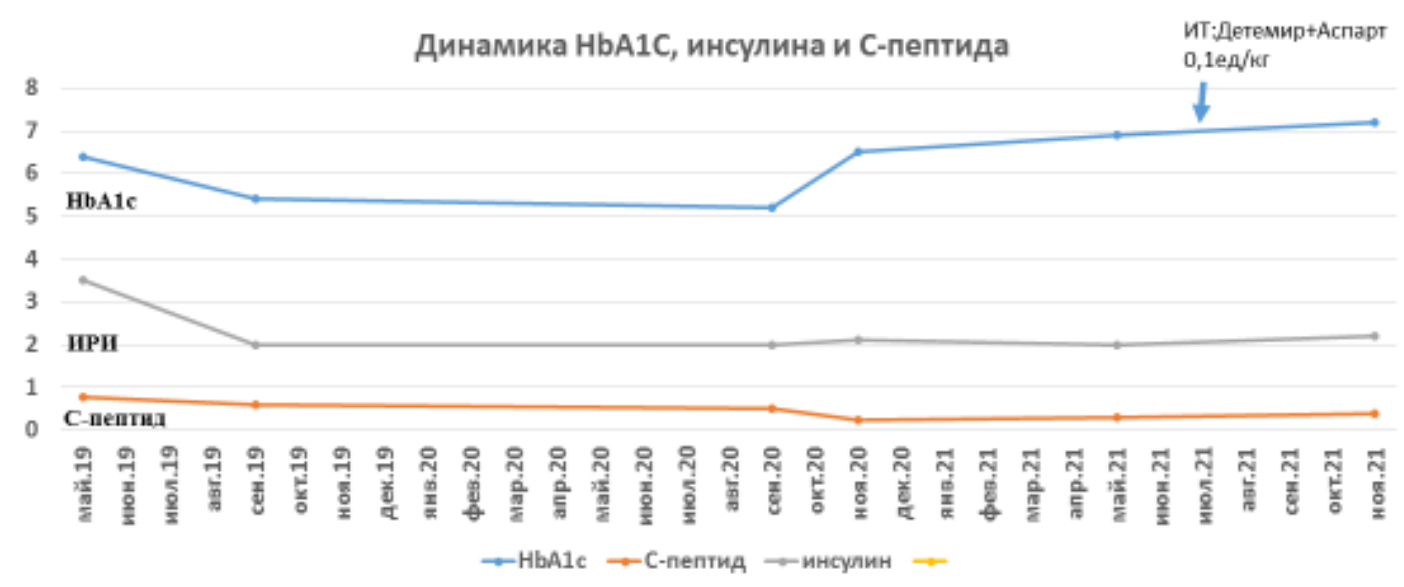

У пациента выявлена сопутствующая патология: гепатомегалия, хронический холецистит, деформации желчного пузыря, холестириновые полипы желчного пузыря. Неврологом диагностировано расстройство вегетативной нервной системы. 
За весь период заболевания не отмечалось повышения титра специфических аутоантител.

Таблица 1. Динамика уровня специфических аутоантител

\begin{tabular}{|c|c|c|c|c|c|c|}
\hline & Референс & 09.2019 & 02.2020 & 11.2020 & 08.2021 & 10.2021 \\
\hline GAD & $0-10$ & $<0,4$ & $<0,4$ & 0,17 & 0,36 & \\
\hline IA2 & $0-10$ & 0,03 & 2,29 & 0,07 & 0,03 & \\
\hline ZnT8 & $0-15$ & & & & & $<10$ \\
\hline ICA & $<4$ & $<1,14$ & $<4$ & 0,18 & отр & \\
\hline IAA & $0-10$ & 5,37 & & 1,7 & 4,71 & \\
\hline
\end{tabular}

В связи с нетипичной картиной заболевания, длительной ремиссией, отсутствием повышения титра аутоантител проведено Секвенирование панели генов «Сахарный диабет» (27 генов): патогенных и вероятно патогенных вариантов не обнаружено.

Компенсация углеводного обмена достигнута посредством ИТ в дозе 20 ЕД/сут.(0,3 ЕД/кг/сут) на фоне расширения питания до $15 \mathrm{XE}$ в сутки. Психологом диагностировано расстройство пищевого поведения, проявляющееся в постоянном чувстве голода, отсутствии насыщения от потребляемой пищи в рамках диеты, сильном желании к расширению рациона питания и присутствии на фоне всего этого блоков и боязни к введению достаточного количества углеводов в рацион на долгосрочной перспективе.

В связи с негативным отношением пациента и его мамы к инсулинотерапии после выписки из стационара вернулись к привычному низкоуглеводному безглютеновому питанию (7-8 ХЕ/сут.), ИТ 12-13 ЕД/сут. (0,2 ЕД/сут).

\section{Заключение:}

У пациента наблюдалась мягкая манифестация Идиопатического СД 1 типа на фоне ранней доклинической диагностики, отсутствие кетоза в течение всего периода заболевания и отсутствие повышения титра специфических аутоантител, что суммарно привело к подозрению на наличие у пациента моногенных форм сахарного диабета. Однако при полноценном обследовании и достаточном расширении рациона питания очевидно наличие у пациента сахарного диабета 1 типа, инсулинопотребного.

Соблюдение безглютеновой диеты, низкий гликемический индекс используемых в рационе продуктов, дробное питание способствовали продолжительной ремиссии с поддержанием HbA1c в диапазоне 5,3$6,5 \%$.

По мере прогрессирования дисфункции b-клеток потребовалось назначение ИТ, соблюдение строгой крайне низкоуглеводной безглютеновой диеты не является полезным для пациента. Ограничения в питании, длительное отсутствие адекватного количества углеводов в рационе ребенка, употребление только низкоуглеводных и безгютеновых продуктов привели к расстройству пищевого поведения. 